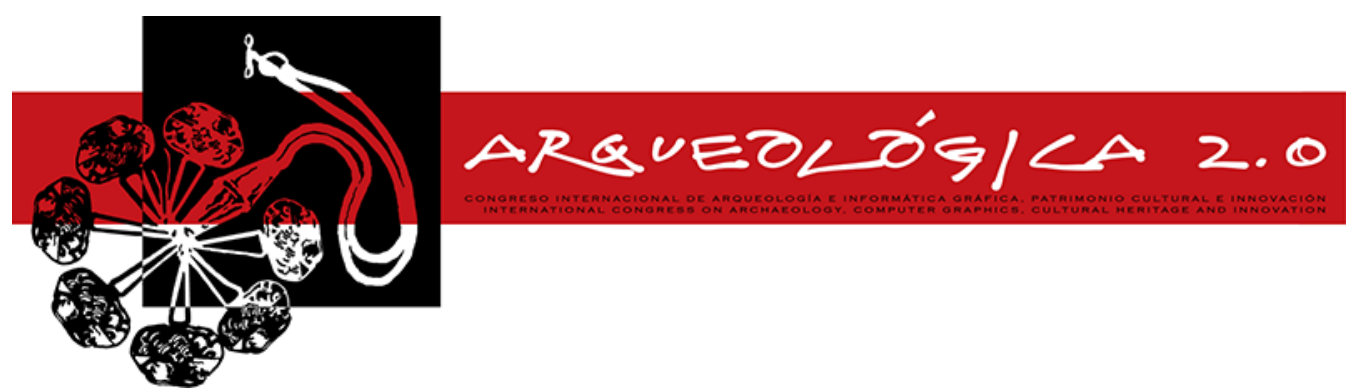

Proceedings of the $8^{\text {th }}$ International Congress

on Archaeology,

Computer Graphics,

Cultural Heritage and Innovation

'ARQUEOLÓGICA 2.0'

in Valencia (Spain),

Sept. $5-7,2016$

DOI: http://dx.doi.org/10.4995/arqueologica8.2016.3555

Received: 01/03/2016

Accepted: 10/04/2016

\title{
INTEGRATED METHODOLOGIES FOR A NEW RECONSTRUCTIVE PROPOSAL OF THE AMPHITHEATRE OF CATANIA
}

\author{
METODOLOGÍAS INTEGRADAS PARA UNA NUEVA PROPUESTA RECONSTRUCTIVA DEL ANFITEATRO DE \\ CATANIA
}

\author{
Daniele Malfitana, Francesco Gabellone*, Giovanni Leucci, Giuseppe Cacciaguerra, Ivan Ferrari, \\ Francesco Giuri, Lara De Giorgi, Claudia Pantellaro
}

CNR - IBAM (Istituto per i Beni Archeologici e Monumentali), Via prov.le Monteroni, 73100 Lecce, Italy. d.malfitana@ibam.cnr.it; f.gabellone@ibam.cnr.it; g.leucci@ibam.cnr.it; g.cacciaguerra@ibam.cnr.it; i.ferrari@ibam.cnr.it; f.giuri@ibam.cnr.it; I.degiorgi@ibam.cnr.it; c.pantellaro@ibam.cnr.it

\begin{abstract}
:
The roman amphitheatre of Catania stands in a very complex and interesting area where settlement dynamics and transformations have profoundly marked its urban landscape. Over the centuries, the urban and architectural histories together with the formation of the archaeological deposits have led to the complete obliteration of the monument and restricted knowledge of its plan and architectural development. Therefore, it constitutes an interesting context in which to experiment methods and techniques for architectural representation and the three-dimensional reconstruction of the monument.
\end{abstract}

Key words: virtual archaeology, digital archaeology, integrated technologies, 3D reconstruction, amphitheatre

\section{Resumen:}

El anfiteatro romano de Catania se encuentra en una zona compleja e interesante donde la dinámica de asentamiento y transformaciones han marcado profundamente su paisaje urbano. A través de los siglos, las historias urbanas y arquitectónicas, junto con la formación de los depósitos arqueológicos han dado lugar a la destrucción completa del monumento y el conocimiento de su plan de desarrollo arquitectónico. Por lo tanto, constituye un contexto interesante en el que experimentar métodos y técnicas para la representación de la arquitectura y la reconstrucción tridimensional del monumento.

Palabras clave: arqueología virtual, arqueología digital, tecnologías integradas, reconstrucción 3D, anfiteatro

\section{The Roman amphitheatre: research to date}

The Roman amphitheatre was built in the early imperial period on the northern edge of the ancient city. There are few references to the amphitheatre in the sources and there is no mention of it before the $6^{\text {th }}$ century A.D. when Cassiodorus mentions the concession granted by Theodoric to the people of Catania allowing them to reuse stone blocks from the Roman monument for the construction of the city walls (Cassiodorus, Variae III, 49). From the $16^{\text {th }}$ century the amphitheatre is cited and described several times by scholars and corographers and represented in numerous historical views and maps that give its exact position within the urban fabric of the modern city (Fig. 1), documenting the material and architectural substance of its structures (Fazello 1558;
Spannocchi 1578; Hogenberg 1598; De Grossis 164247; Carrera 1639; Negro 1640).

However, the amphitheatre's structures were definitively buried when the structures were razed in 1618 (D'Arcangelo 1621, III, p. 11). Although well-known by the townspeople, the structures were completely obliterated and no longer considered within the reconstruction plan that followed the 1693 earthquake and subsequent construction expansion that took place in the area between the mid $18^{\text {th }}$ and the $19^{\text {th }}$ centuries (Boscarino 1981; Oteri 2002, p. 45).

However, during the $18^{\text {th }}$ century Ignazio Paternò Castello V, Prince of Biscari, renewed study of the amphitheatre. He excavated the buried structures, uncovering large sections of the ground floor. At the same time, J-P. Houel and other French (Ducros 1778)

*Corresponding Author: Francesco Gabellone, f.gabellone@ibam.cnr.it 
and Dutch travellers described and drew the amphitheatre providing us with details of the visible portions of the monument and hypothetical reconstructions.

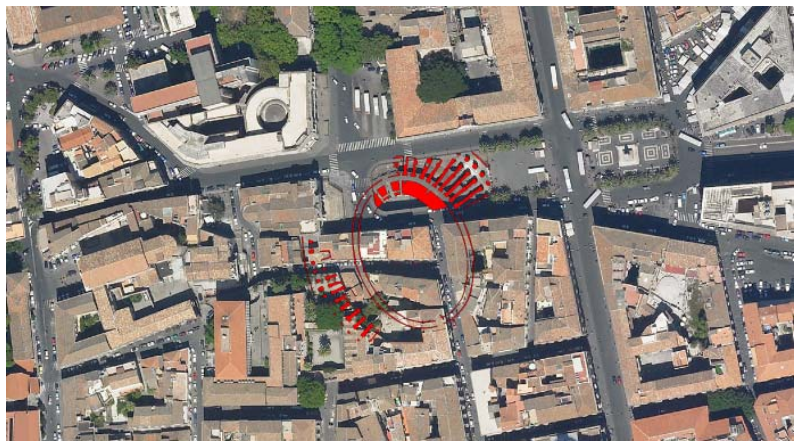

Figure 1: The structure of the amphitheatre over the actual city.

Between 1904 and 1905, an invasive excavation undertaken in Piazza Stesicoro by the engineer $F$. Fichera brought to light a portion of the area and the northernmost sectors of the structure (Fichera 1904; Fichera 1905). However, the absence of excavation records means that this intervention did not improve knowledge of the monument. In particular, the excavations identified part of the ima cavea in the northeastern sector, with a service corridor and podium wall that still preserved parts of its marble facing. An "unusual" praecintio was identified, about $6 \mathrm{~m}$ wide built on top of the internal walkway. He imagined the structure to be crowned by a portico with a colonnade of Ionic columns. At the end of the excavations the entire route of the first walkway was opened up and part of the first two sectors of seating tiers with the underlying radial spaces delimited by a peripheral corridor were visible.

Therefore, at the end of the 1990s a systematic study had still not been made of Catania's amphitheatre and it remained largely unpublished (Wilson 1990). Between 2006 and 2007, the data acquired during research undertaken by the German Institute of Archaeology in collaboration with the Superintendency of Catania provided a better understanding of some structural and architectural aspects of the Roman amphitheatre and identified the phases of construction and enlargement (Beste et al. 2007).Two different construction phases were documented. In the first, dated to the early imperial period (contra Buscemi 2012), the amphitheatre was much smaller. The second is attributable to the Antonine period, suggested by the use of opus africanum for the facing of the radial dividing walls and, above all by the structural discontinuity documenting interventions to enlarge the entire building. This involved the extension of the existing sectors by the creation of a wide external walkway with a façade ornamented with pilasters. This operation led to the choice of complex architectural and engineering solutions such as the partial excavation of the hillside and the creation of entrances on upper levels directly from the hill of Montevirgine. Thus, the amphitheatre became one of the city's cardinal points, situated on its outskirts in an area linking the city centre with the suburbs.

Furthermore, recent archaeological investigations, carried out to the west and north of the monument, documented evidence about the context in which it stood. In fact, they provided useful elements suggesting the presence of a residential district in this sector of the city in the Republican period (Branciforti 2003, pp. 113114; Branciforti 2005, pp. 186-187; Branciforti 2010, pp. 221-222), with quite wealthy domus, the result of an important phase of urban development which also effected other parts of the city. The building of the amphitheatre in the early imperial period was probably a "traumatic" intervention leading to the reorganisation of the urban layout in this sector of the roman city that perhaps determined the demolition of a part of the preexisting residential quarter. (DM, GC, CP).

\section{The reconstruction of the discovery}

The research undertaken by IBAM-CNR between 2014 and 2015 aimed towards obtaining a three-dimensional reconstruction of the monument by combining diverse methods of data acquisition and processing. This made it possible to acquire important data for the creation of an exact reproduction of the parts of the monument that are still hidden and provide a faithful reconstruction of the entire architectural structure.

\subsection{The integrated archaeological and geophysical investigations}

The integration of the archaeological data with that acquired by the geophysical surveys (ERT and GPR) improved knowledge of the monument within its actual topographical position in relation to the context of the Roman city and made it possible to reconstruct the relationship with the Montevergine hill. In addition, a number of hypotheses formulated in the past were confirmed and new important data acquired regarding the architectural development of several parts of the monument. From the model of the resistivity distribution is evident the presence of a heterogeneous subsoil with an area of regular shape. The area allows to know the development of the amphitheatre below the city. The data processing has enabled us to reconstruct the 3D development of the amphitheatre and, using the results of the geoelectric survey, it was possible to reconstruct the probable ancient walking surface in Roman times. The research also made it possible to state that the arena was partially excavated in the rock within what was the geological basis (Fig. 2).
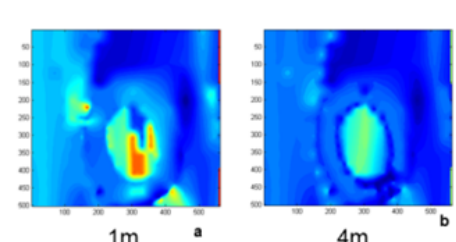

$4 \mathrm{~m}$

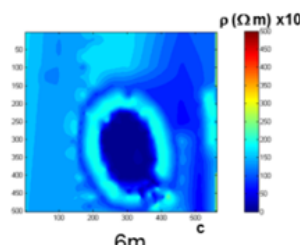

$6 \mathrm{~m}$
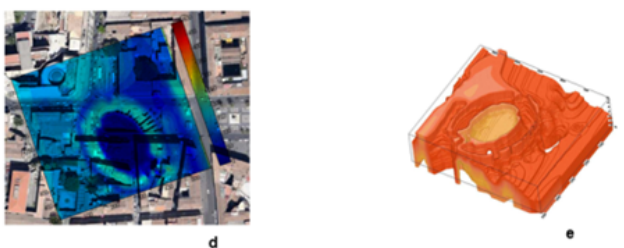

Figure 2: Geophysical prospection indicate the overall dimensions of the building.

The data on the relationship with the hill slope offered a new important evidence. Recent excavations carried out 
in the area of Sant'Agata al Carcere had identified a small temple on a podium, dating to the $2^{\text {nd }}$ century A.D. It was aligned on an east-west axis and standing on the summit of a short stretch of supporting wall decorated with three deep niches (Arcifa 2010; Patanè et al. 2010; Malfitana et al. 2015). However, although associated with the amphitheatre, its exact topographic and architectural relationship had not been explained. The geophysical investigations, combined with an analysis of the ancient and present levels, made it possible to identify an anomaly situated along the same axis as the three niches at the base of the small imperial temple. Therefore, it is compatible with a long structure that supported a great terrace on which the small cult building stood in the imperial period. A large open space developed below it, perhaps on a slight slope, which facilitated and served the entrance to the amphitheatre on an upper level, confirming what was already suggested by earlier research (Beste et al. 2007). (GL, LDG, GC, CP).

\subsection{The survey and graphic rendering of the amphitheatre of Catania}

The metric analysis of the survey, reveals, between hypotheses and confirmations, the morphological aspects and the stratigraphy of the structure, an absolute necessity for any formulation of a hypothetical reconstruction. Every context constitutes a separate case, which presents different questions and peculiarities, which make the use of 3D survey indispensible for the basic documentation and analysis of an architectural organism.

In this process, the contribution of the 3D modelling software is not limited to the pure generation and manipulation of the polygons in the space, but is outstanding in its capacity to facilitate the interpretative processes. In the limited time available to many projects, it would certainly be impossible to examine numerous considerations regarding equilibrium of the proportions, the juxtaposition of the volumes, the application of the laws of statics, neither would it be easy to examine such questions on a vast scale using traditional drawing methods. It is therefore fundamental to recognise 3D modelling software's substantial contribution to the study of ancient monuments. The greater three-dimensional awareness of an architectural organism provided by the modelling environment makes it possible to go into greater detail and have more control over the different reconstruction phases, with a notable increase in precision, productivity and capacity to respond to specific problems imposed by the observation and study of monuments within a space. It would be mistaken and restrictive to consider $3 \mathrm{D}$ modelling as merely one of the new representational tools that simply replace the drafting pen or pencil. The role of the virtual archaeology specialist is closely connected to the dialectic relationship between classical studies and the possibilities offered by these tools for 3D modelling and simulation. Only through constant checks in 3D of technical and construction, dimensional and spatial aspects is it possible to validate the hypotheses that are formed from the philological study of the sources, archaeological data, and contemporary parallels. Many original results achieved by mixed teams of classical scholars and specialists in virtual archaeology have been possible thanks to the verification and study of the monuments in the 3D environment. This is because only a minimal part of the proposed reconstruction is revealed to be plausible and compatible with the functional logic and construction and stylistic principles used by a particular civilisation, in a precise historical period.

In the case of Catania's Roman amphitheatre the decision was made to combine different methods and tools in order to obtain an exhaustive representation of the architectural geometry and its specific materiality, beginning with a numerical model of the state of preservation of the surviving structures. Two separate indirect survey methods were employed using both active sensors and passive sensors for different purposes.

A Leica ScanStation 2 laser scanner was used to survey the part of the amphitheatre situated in Piazza Stesicoro and part of the rooms that are known but cannot be entered situated underneath Villa Cerami. The parts of the city surrounding the monument were also surveyed (Figs. 3, 4b).

In addition to the laser scanner, it was possible, although only for the part of the amphitheatre in Piazza Stesicoro, to use 3D rendering techniques from photographs, able to provide a digital model with a high level of detail, geometric accuracy, photorealism, and portability. In particular, the elevated photorealism of the surfaces that could be reached using these techniques overcomes the limitations of the camera combined with the laser scanner and is indispensible in the study and identification of materials, construction techniques and phases. These systems, using SfM (Structure from Motion) algorithms completed by stereo matching operations, are the result of the convergence of different disciplines, on the one hand Computer Vision for automatism in the generation of 3D models, on the other hand photogrammetry for the measurable documentation of the object.

The entire photographic campaign (c. 350 photos) was carried out using a full frame digital reflex camera (Canon 5D Mark II-21 MPix). Care was taken to maintain the focal length $(24 \mathrm{~mm})$ and width of sampling constant in order to cover the entire surface of the objects and guarantee sufficient overlapping of the images, which is indispensible for the identification and association of corresponding points. The photographs were taken in environmental conditions that guaranteed diffused luminosity without excessive contrast between zones in light or in shade. Subsequently, all the photographs were processed using Photoscan by Agisoft, proceeding with the alignment of the shots, the creation of the points cloud (c. $88 \mathrm{mln}$ ), the mesh, and processing of the textures at a resolution of $15000 \times 15000 \mathrm{px}$. The model created has a high level of metric accuracy, equal to that of the laser scanner, with the advantage of also having the surface colour that is vital for the study of building techniques and materials. Elements which, thanks to the availability of a complete texture model, can be perfectly identified and measured (Fig. 5). 


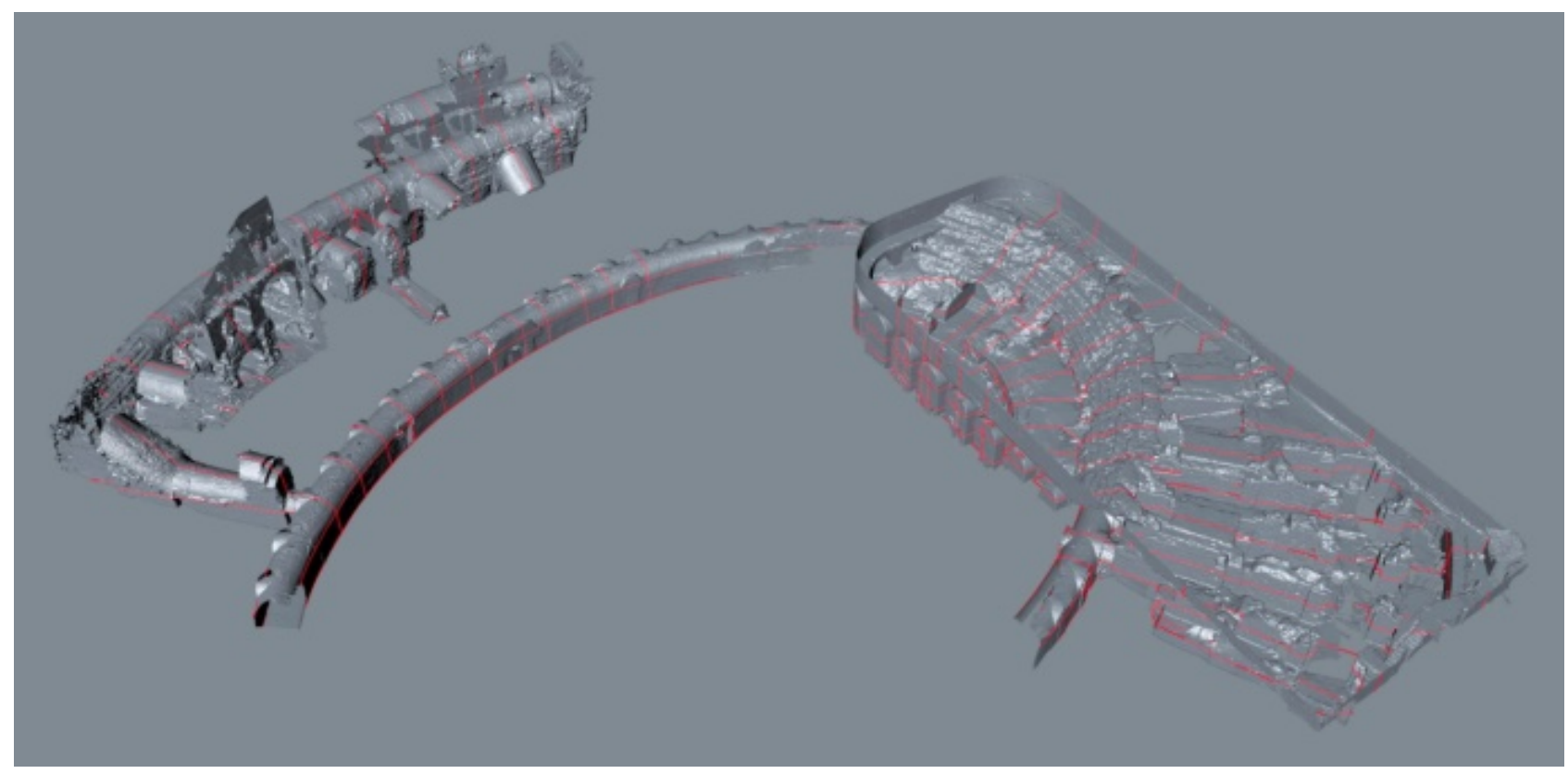

Figure 3: Laser scanner survey with the sections line used for the 3D reconstructive study.

A

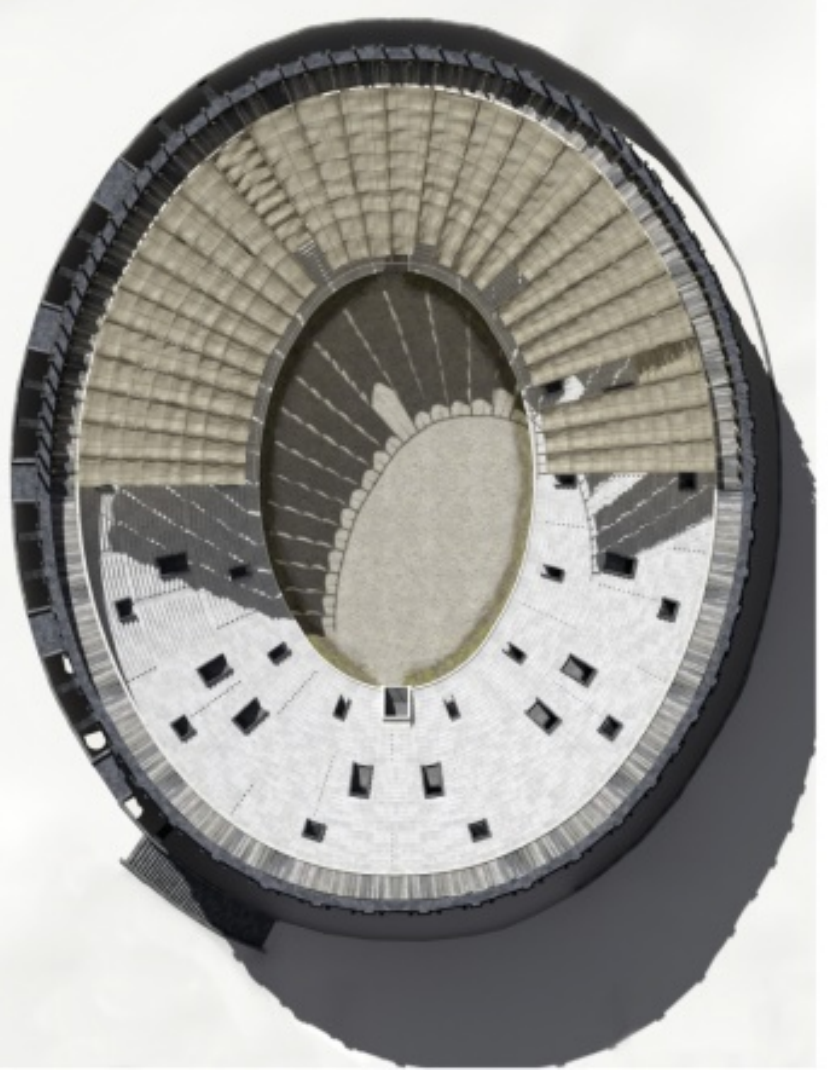

B

Figure 4: Reconstructive hypothesis of the second phase (A) and 3D survey of accessible sectors (B).

The processing of the data from the combined techniques of laser scanning and photogrammetry have been used for the production of the planimetric sections. Indeed, the methodological rigour and uniformity of the data produced by the laser instrumentation and structure from motion systems made it possible to manage the entire mass of information within the same 3D workspace. Two identical models are used, predisposed to provide all the information, about both geometry and colour, that is far more complete, much faster and with a far superior level of accuracy than information accessible via the traditional techniques of direct survey. The combination of these technologies demonstrates how the characteristics of the individual tools have a level of complementarity that renders a combined system more performing and flexible, able to produce a much better 
result in absolute terms and able to adapt to the individual morphology of the various subjects contained within the surveyed scene. The result is a cognitive digital model, in other words a container of various levels of information, which through comparison with known examples of coeval amphitheatres makes it possible to investigate analogies for the building techniques in use during the construction period, but above all to examine the particular construction solutions adopted for this monument. (FGa, IF, FGi).

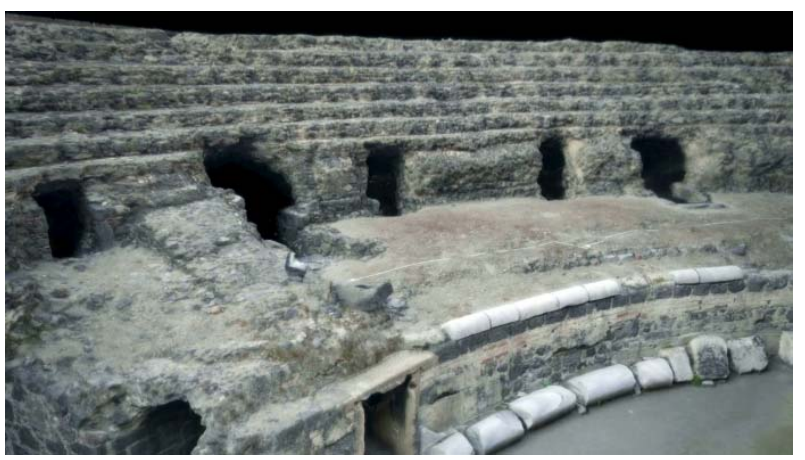

Figure 5: Image-Based survey useful for the detailed study.

\section{The 3D Reconstruction of Amphitheatre}

During the processing of a hypothetical reconstruction of Catania's Roman amphitheatre, it was necessary to deal with a series of construction questions highlighted by the analysis of the most recent survey, which led, at least in some specific aspects, to original interpretative solutions.

Hypothetical reconstruction of phase 1 . The important contribution provided by the German Archaeological Institute in 2006 and 2007 (Beste et al. 2007), verified the existence of two distinct construction phases, the first constituted by a structure datable to the early imperial period that was smaller than the later monument that was enlarged probably during the Antonine period.

At first, the structure's plan presumably formed an oval with the maximum dimensions of c. $80 \mathrm{~m}$. by $100 \mathrm{~m}$. The size of the arena was more or less the same as the present one (c. $40 \times 60 \mathrm{~m}$.) and was accessed via the two main entrances, situated on the main axis, with two small lateral entrances. The only walkway presents in this phase developed concentrically around the arena at about $6 \mathrm{~m}$ from it, was $3 \mathrm{~m}$ wide and its floor surface was about $1 \mathrm{~m}$ higher. Originally, the radial dividing walls were no more than $10.5 \mathrm{~m}$ in length and are still recognizable by their different construction technique and the presence of an offset that constituted the external head of the wall. An overall look at the plan highlights an important fact, the imperfect symmetry of the monument whose axes are just one degree off being perfectly orthogonal. For the sake of convenience, one quarter of the structure was analysed. Fourteen radial walls are present, delimiting corridors that flare towards the exterior, sometimes interconnected by openings, topped by the oblique vaults in opus caementicium that supported the cavea. Arched passageways linked the radial corridors to the walkway, from which three separate flights of steps were reached, two situated close to the main axes and a third in an intermediate position, which led into the three vomitoria providing access to the imacavea. However, the problem of access to the summa cavea remains, perhaps resolved by the creation of external ramps, which via openings in the upper crowning wall, made it possible to reach the annular passageway of the summa cavea. This arrangement finds parallels with other typologically similar structures present in other Roman cities, for example the amphitheatre at Pompeii, perhaps coeval with the one in Catania. This solution could have been adopted later between the $2^{\text {nd }}$ and $3^{\text {rd }}$ centuries A.D. in Catania's Roman theatre.

Hypothetical reconstruction of phase 2. The desire to increase the capacity of the structure, but at the same time exploit what already existed, can be clearly perceived in this phase. It is possible to distinguish several elements that differ in construction technique and morphology. The enlargement of the cavea can be seen in the elongation of the individual radial walls and the creation of two superimposed annular walkways, supported externally by a series of pillars in opus quadratum with a cruciform section, on the same axes as the individual walls. Pairs of corbels inserted in the side of the pillars support the brick-built arched lintels that distinguish the two orders of the amphitheatre, which particularly in proximity to the main axis become segmental arches, in order to adapt to the wider bays between the dividing walls (Fig. 4).

Regarding the slope of the cavea, the suggestion that there was a large praecentio immediately abutting the area is no longer considered viable, a doubt already expressed by R. Wilson and F. Buscemi (Wilson 1990; Buscemi 2012). These observations are based on the fact that the profile of the seating tiers, highlighted in the sections, must necessarily have been further forward due to the presence of blocks that must originally have faced the conglomerate. In the second place, it can be seen how the conglomerate partly continues the oblique profile, in particular on the sides of the entrance to the arena in correspondence with the main axis, and the absence of a jump in height noted. The space remaining between the last step of the cavea (as visible today) and the arena's parapet would thus determine a continuous descending profile, terminating in a praecentio of reduced dimensions but large enough to allow the flow of spectators.

The vomitoria from phase one were kept to allow access to the ima cavea, while the problem of access to the media and summa cavea remained to be solved. The absence of stairs providing a link from the first order to the second also justifies the absence of an intermediate walkway situated between the inner one abutting the arena and the superimposed outer ones. This is a peculiarity of the amphitheatre in Catania that probably derives from the topographical context and urban layout in which the structure was built, immediately abutting a rocky slope that was then cut in order to enlarge it. This means that, in the western sector, all of the first order of the second phase was situated below the ground level of the ancient city (Arcifa 2010; Patanè et al. 2010). This resulted in an extremely unusual distribution system that resolved access to the building via passageways on an upper level running above the corridor abutting the rock face and leading directly into the outer walkway. In this sense, it is likely that following the structure's enlargement, the greatest flow of spectators must have 
been concentrated in the point of easiest access to the city, precisely on the western side. This would explain how the only access points to the ima and summa cavea led out from this walkway. As regards the link from the upper external walkway to the media cavea, when the structure was enlarged the construction of barrel vaults with a flat extrados was planned (fig. $4 \mathrm{~b}$, sector 46 ). These were built on and supported by the dividing walls that were partly reinforced by thickening their width (this is clearly visible in the different construction technique), with a downward sloping diagonal line in the first portion to support a flight of steps. At the end of this ramp, a flat part is visible, at the end of which another short flight of steps must have led to the vomitoria situated on an intermediate diazoma in the cavea.

As can be noted by observing sector 39 , a diagonal vault, also beginning from the upper external walkway but this time ascending, must have supported another flight of steps that provided access to the vomitoria in the summa cavea. Using the survey data, an attempt has been made to understand the distribution of these passageways and therefore the distribution of the diverse vomitoria, which in the three-dimensional reconstruction tend to assume a particular distribution, probably as a consequence of the compromise deriving from the fusion and adaptation of the old project with the new and more capacious structure (Fig. 6).

The top of the cavea was probably crowned by a portico of Ionic columns, with regular pairs of corbels incorporated into the external face of the rear wall, some of which still present among the amphitheatre's structures. The corbels would have supported the velarium and there must have been two orders, the first and lower one to support the vertical weight of the masts, the second, and upper ones had a square socket into which the which the wooden mast was inserted (Fig. 7). Unlike other and larger structures such as the Colosseum, where the entire awning system was anchored by ropes, a self-supporting system was presumably used in the amphitheatre at Catania, a suggestion justified by the smaller awnings, the notable radial space to be covered and by the morphology of the terrain surrounding the building, which presented substantial variations in height.

This element introduces another important consideration that emerged from the contextualisation of the monument within the urban topography of ancient Catania. In fact, contrary to the western area where the entrances are on an upper level, in the portion in front of the area south of the amphitheatre in correspondence with the main axis, excavations have shown that the ground level of the Roman city must have been more or less at the level of the first order (Beste et al. 2007; Arcifa 2010; Patanè et al. 2010; Malfitana et al. 2015). This would suggest that precisely in this point there was an entrance on this level into the amphitheatre (Fig. 8). Therefore, a substantial difference in height must have distinguished the two access areas, very probably linked by ramps or steps. Today, a containing wall is visible in the north-eastern sector in Piazza Stesicoro, which indicates that in this part the rock face tends to rise, presumably to then join with the level of the terrace on which the entrances in the second order were situated (Fig. 9). (FGa, IF, FGi)
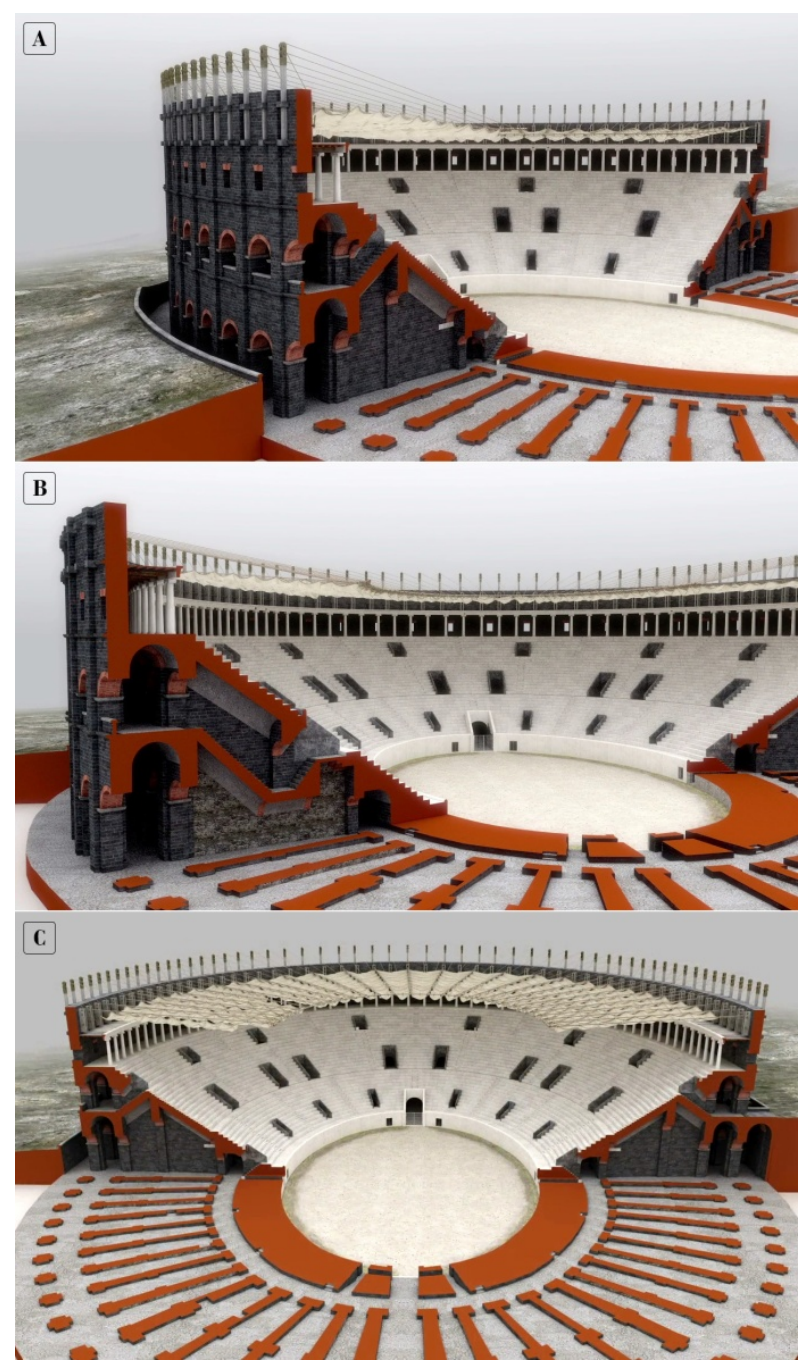

Figure 6: Several sections of the amphitheatre shows internal distribution paths of the hypothetical reconstruction of the second phase.

This element introduces another important consideration that emerged from the contextualisation of the monument within the urban topography of ancient Catania. In fact, contrary to the western area where the entrances are on an upper level, in the portion in front of the area south of the amphitheatre in correspondence with the main axis, excavations have shown that the ground level of the Roman city must have been more or less at the level of the first order (Beste et al. 2007; Arcifa 2010; Patanè et al. 2010; Malfitana et al. 2015). This would suggest that precisely in this point there was an entrance on this level into the amphitheatre (Fig. 8). Therefore, a substantial difference in height must have distinguished the two access areas, very probably linked by ramps or steps. Today, a containing wall is visible in the north-eastern sector in Piazza Stesicoro, which indicates that in this part the rock face tends to rise, presumably to then join with the level of the terrace on which the entrances in the second order were situated (Fig. 9). (FGa, IF, FGi) 
$\mathbf{A}$

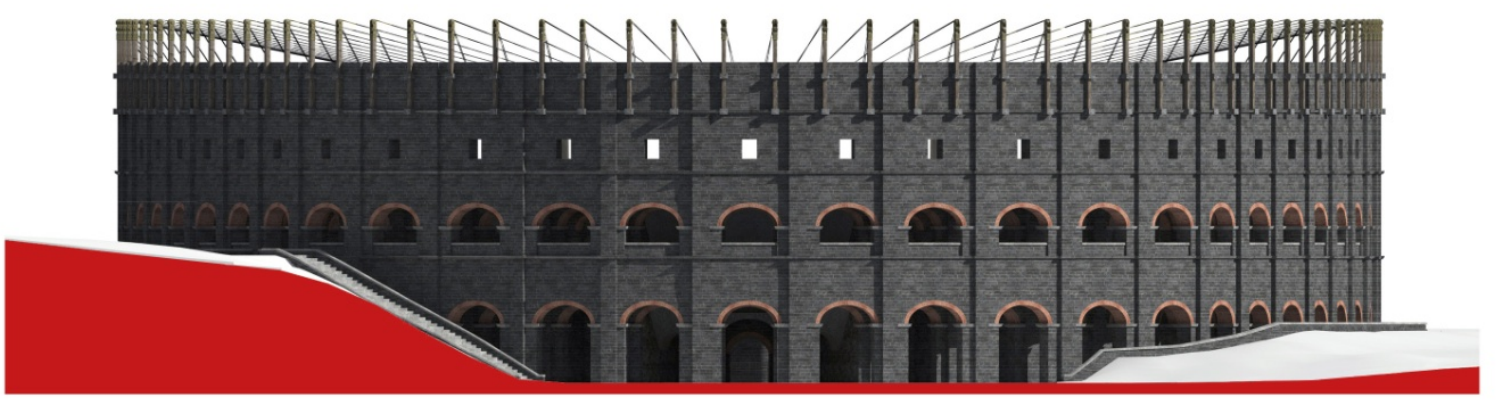

B
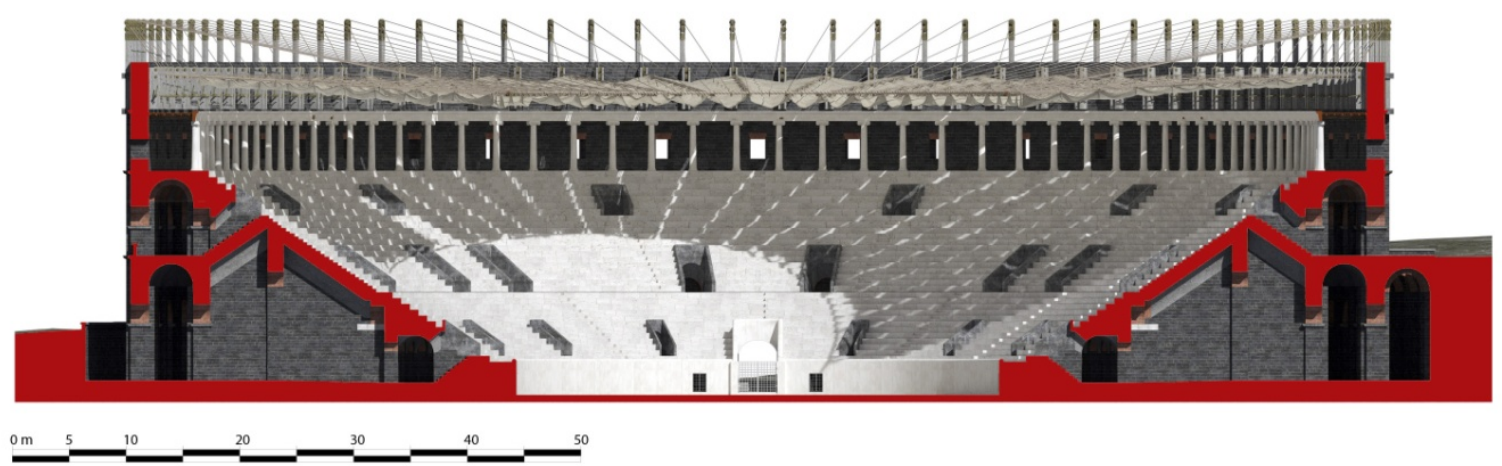

Figure 7: Reconstructive hypothesis of the second phase: front view (A) and section in correspondence of the minor axis (B).

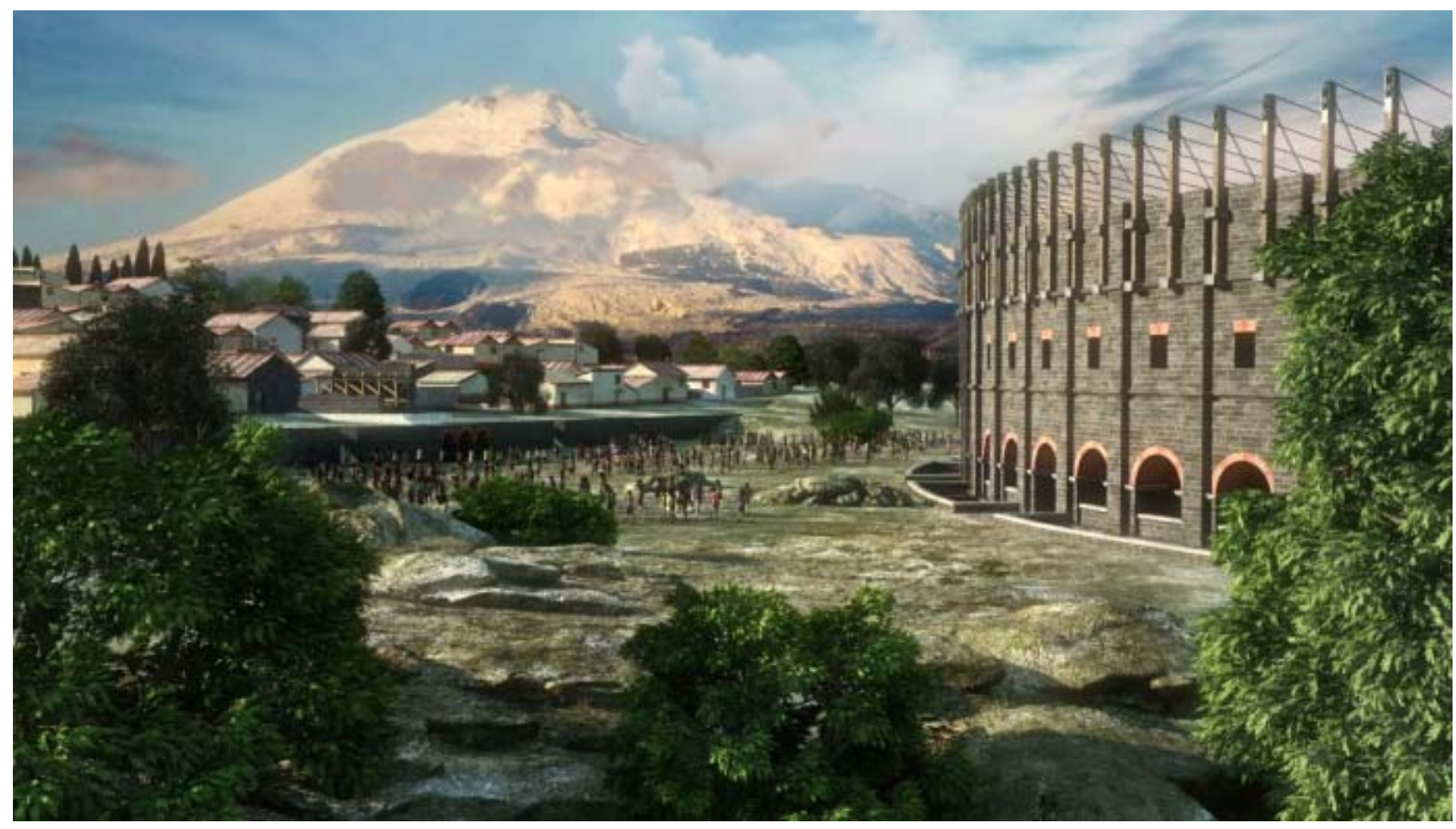

Figure 8: Screen shot of informative movie. The access to the building via passageways from the terrace level in the last phase.

\section{Conclusion}

In the last years the amphitheatre of Catania has been the focus of several studies, especially with the aimed to identify the different chronological phases and to interpret the different structural features. This work, entirely done with methods and techniques of Virtual Archaeology, aims to provide new interpretations of some structural phases that outline the salient features of an extremely unusual monument. The threedimensional study of the status quo, traced with the aid of laser scanning, has clarified the entire morphology and the 3D representation of those hidden parts located below the modern buildings. The integration of relief with the archaeological data made it possible to reconstruct a probable architectural development of the building, with its tight integration with the surrounding orography. The system of accesses at different altitude and the use of 
the lava stone denote an identity with strong colour accents combined with a distribution solution of great interest, that the movie reconstruction for public dissemination of the results tells a simple and effective language.

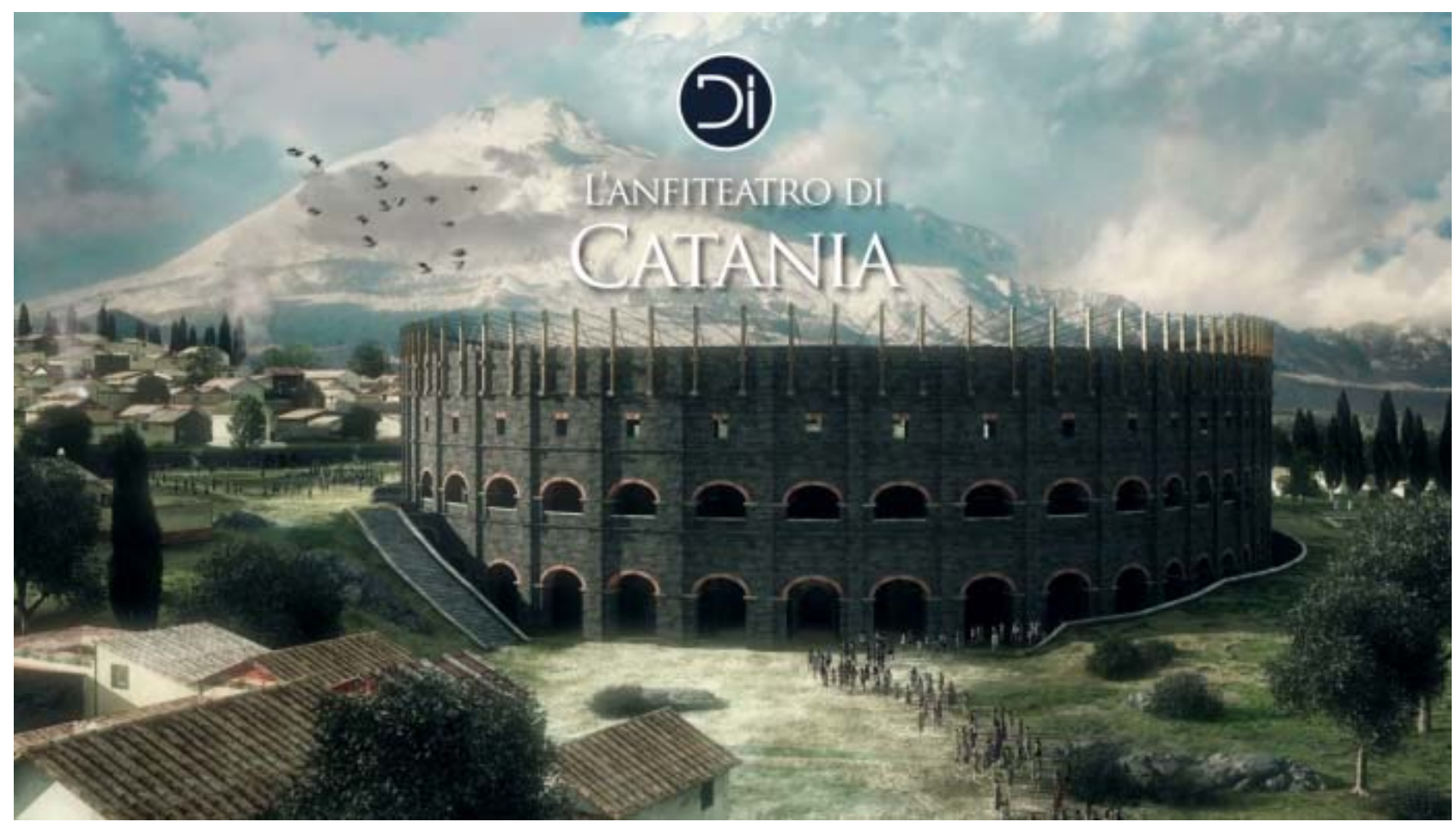

Figure 9: Reconstructive hypothesis with the various access from the city.

\section{References}

ARCIFA, L., 2010. Da Agata al liotru: la costruzione dell'identità urbana nell'alto Medioevo, in: M.G. Branciforti, V. La Rosa (eds.), Tra lava e mare. Contributi all'archaiologia di Catania, Catania, pp. 355-386.

BESTE, H.J., BECKER, F., SPIGO, U. 2007. Studio e rilievo sull'anfiteatro romano di Catania, in: Mitteilungendes Deutschen Archaologischen Instituts - Romische Abteilung, 113, pp. 595-613.

BRANCIFORTI, M.G. 2003. Quartieri di età ellenistica e romana a Catania, in: G. Fiorentini, M. Caltabiano, A. Calderone (eds.), Archeologia del Mediterraneo. Studi in onore di Ernesto De Miro, Roma, pp. 95-120.

BRANCIFORTI, M.G. 2005. Catania. Dalla preistoria al Medioevo, in Dall'Alcantara agli Iblei. La ricerca archeologica in provincia di Catania, in: F. Privitera, U. Spigo (eds.), Palermo, pp. 175-200.

BRANCIFORTI, M.G., 2010. Da Katane a Catina, in: M.G. Branciforti, V. La Rosa (eds.), Tra lava e mare. Contributi all'archaiologia di Catania, Catania, pp. 183-209.

BUSCEMI, F., 2012. Architettura e romanizzazione della Sicilia di età imperiale: gli edifici per spettacoli. Palermo.

FICHERA, F., 1904. Scavi dello Anfiteatro, in: Archivio Storico per la Sicilia orientale, pp. 119-120.

FICHERA, F., 1905. Per lo anfiteatro di Catania, in: Archivio Storico per la Sicilia orientale, pp. 66-72.

GABELLONE, F., 2012. La trasparenza scientifica in archeologia virtuale. Una lettura critica al Principio N.7 della Carta di Siviglia, in: CASPUR CIBER Publishing SCIRES-IT, SClentific RESearch and Information Technology, vol. 2, Issue 2 (2012), pp. 99-124.

GABELLONE, F., FERRARI, I., GIURI, F., 2015. Digital restoration using Image-Based 3D models, in: Proceedings of the 1st International Conference on Metrology for Archaeology, Benevento - Italy, October 21-23, 2015, Benevento, pp. 534- 538.

GABELLONE, F., FERRARI, I., GIURI, F., CHIFFI, M., 2015. The contribution of the 3D study for new reconstructive proposals of Lecce in Roman age, in: Proceedings of the 1st International Conference on Metrology for Archaeology, Benevento - Italy, October 21-23, 2015, Benevento, pp. 534-538.

MALFitANA, D., CACciaguerRA, G., BARONE, S., MAZZAGLIA, A., NOTI, V., LEUCCI, G., DE GIORGI, L., CANNATA, A., PANTELLARO, C., SCROFANI, M.L., 2015. OPENCiTy Project: un progetto per l'archeologia urbana, la pianificazione lo sviluppo sostenibile di Catania. La valutazione del potenziale archeologico: primi dati, in: $F$. Anichini, G. Gattiglia, M.L. Gualandieds., MAPPA Data Book 1. I dati dell'archeologia urbana italiana, Roma, pp. 1738. 
OTERI, A.M., 2002. Riparo, conservazione, restauro nella Sicilia orientale o del "diffinitivo assetto" 1860-1902, Roma.

PATANĖ, A., TANASI, D., CALÌ, D., 2010. Indagini archeologiche a Sant'Agata la Vetere e Sant'Agata al Carcere, in: M.G. Branciforti, V. La Rosa (eds.), Tra lava e mare. Contributi all'archaiologia di Catania, Catania, pp. 337-354.

WILSON, R.J.A., 1990. Sicily under the Roman Empire. The archaeology of a Roman province. 36 B.C. - A.D. 535 , Warminster. 